DOI: $10.17148 / I A R J S E T .2021 .8810$

\title{
Empowerment of Muslim Women through Madrasas
}

\author{
Afsana $^{1}$ \\ PhD scholar, Department of Sociology, Maulana Azad National Urdu University, Hyderabad, India
}

\begin{abstract}
The society which places woman in a respectable position would be called progressive and developed one. As long as issues like health and literacy related to women are not taken care of, inequities between women and men will continue in the society. Self-employment and education are the means to attain the empowerment of women. Education is such a resource for social change that enhances the development of a society. Muslim communities mostly prefer madrasa education to their children, especially for their girls, due to their poverty. The main purpose of the Madrasas is to provide religious education and to prepare them culturally. This paper deals with the focal point that how far the women are being empowered in the society and at the same time, how much the Madrasas are playing a role in educating and empowering women.
\end{abstract}

Keywords: Empowerment, Muslim Women, Madrasas, Learning.

\section{INTRODUCTION}

In India, women have been highly respected since the past, and among Hindus, women have been honoured by giving them the status of Goddess. But by the time of medieval period, the position of women was deteriorated. As there were several issues such as Sati practice, Jauhar, Child marriage, Purdah System, Lack of women Education, there was always a short in the empowerment of women. There was no improvement either in the British era, because the British purpose was only to rule India, for centuries. The society in which a woman has a respectable place is equally progressive and developed. While building the society, the role of the women is highly essential. In today's era, the situation of women is becoming worrisome, women are not treated socially equal to men, whereas, in western countries, women are given equal status. Women are not considered equal unless issues related to health and literacy of women are not taken into consideration.

Poverty is an obstruction to the empowerment of Women (Nayak and Bidisha 2009) [1]. In order to blow up their socio-economic and political situation, government started various schemes such as Annapurna scheme, Cent Kalyani Scheme, Dena Shakti Scheme, Mudra Yojana Scheme, Mahila Udyam Nidhi Scheme etc. Self-employment and education are the means to attain the empowerment of women. Education is such a resource for social change that enhances the development of a society. According to Emile Durkheim(1956), "Education is an eminently social thing and socialization of the younger generation" [2].

Education makes a person to be a good citizen for the country. It is only through education that a person becomes physically and mentally strong and learns the moral values of a society. Education works to lift the mobility of any society. Education is the progress and social change of a human being. According to the report of 'UNDP 1990', women are lagging behind men economically, socially and politically. Free mobility is such an indicator for women that helps in their empowerment. When compared to urban women, rural women cannot go to the market all alone, even their participation in jobs is around $43 \%$ than that of men. Only $37 \%$ currently married women who work also fail to have autonomy in order to make independent decisions or along with their husbands [1].

Mehra (1997) [3] in his work stated that since1950, the development agencies responded to poor women to make their own income by making small investments, but such projects fail as they are of traditional feminine skills such as knitting and sewing that have limited markets. Hence, not much development of women has been witnessed. In between 1950-90, the life expectancy of women has increased their number in licensed primary schools. In countries such as East Asia and Sub-Saharan Africa, women make up a quarter in their population. Hazarika (2011) states that the Indian Constitution explicitly mentions that women have been given equal position on par with men. Participation of women in Panchayat Raj Institutions in the village is increasing. Women are today serving as the Chief Minister and are participating in other political activities. Despite all these, they are economically backward in nature [4].

\section{ROLE OF MADRASAS FOR THE MUSLIM WOMEN'S EMPOWERMENT.}

Muslim community is the largest minority community in India. Muslim community is far behind other communities in socio-economic, political, and education aspects. Muslim women whether in education or in higher profile, lag behind men when compared to other communities [5]. 


\title{
International Advanced Research Journal in Science, Engineering and Technology
}

\author{
Vol. 8, Issue 8, August 2021
}

\section{DOI: 10.17148/IARJSET.2021.8810}

Biswas (2016), in his study "Higher Education for Muslim Women Empowerment in India", stated that the conservative attitude in Muslim community make them lag behind. Even the purdah system is a barrier for women as they are not allowed to go out [6].

Ali (2001), in his study noted that Muslim communities mostly prefer Madrasa education to their children, especially for their girls, due to their poverty. Despite this, many programs are being run by the government to raise the status of Muslim women. In the $12^{\text {th }}$ Five-Year plan a Scheme was made for Education in Madrasas i.e. "Scheme for Providing Quality Education in Madrasas" [7].

Sikand told that in Muslim, the enthusiasm is found to educate daughters and Ulama and Maulvis are contributing in order to improve Madrasas for high education and the chief characteristic of these Madrasas is to make them religious specialists. Along with higher education, Modern education is also included. In Madrasas, Islamic laws (Sharia'h) are being introduced. Due to which, the girls come to know about their rights and play an eminent role in the society [8].

\subsection{Learning styles in Girls' Madrasas}

Madrasas are playing an important role in empowering girls in the society. Sikand (2005) mentions that the Jamia't-usSalihat Madrasa, located in Malegaon, Maharashtra, is associated with a Deobandi tradition where it has a hostel for girls and a course Fazila degree in which they train them the skills of knitting, stitching and embroidery. The syllabus is based on "National Council for Educational Research and Training". 4000 girls who belong to middle class and study in Jamia Salahiyat Madrasa in Rampur district of Uttar Pradesh and where the syllabus of National Council for Educational Research and Training is being followed [8].

Hem Borker (2018) in his work, "Madrasa and the Making of Islamic Womanhood" performed an ethnographic study on girls at Jamiatul-Mominat Madrasa in Delhi and studied the activities of the girls, in the madrasa and found that the girls are taught how to sit, eat and drink etc. such basic things which make her to become a pious woman. Courses such as sewing embroidery are included in the madrasa. Apart from this, only hardware is included in the Mathematics, English, Cooking, Computer hardware. They are not allowed to run the internet and are forced to offer prayers for five times [9].

"National Commission for Minority Education Institution" reserves fifty percent seats for Muslims. Girls enrol themselves into Universities after the education of Madrasa. This study shows that their identity is made in the society and they can also have self employment. Jeffery (2004) studied 15 madrasas of Bijnor district in Uttar Pradesh and found that there is a lot of difference in the education of girls and boys. Girls' madrasas are mostly Urdu-focused and books like Fazil-e-Amal, Talim-ul-Salam, Basti Jewar and courses of embroidery in girls' madrasas [10].

\subsection{Discussion}

Madrasas are considered only centers of religious knowledge. Mostly girls' madrasas are based on old patterns or religious education. Madrasas lack good quality education. if secular education is included in madrasas, only general subjects are also included in it. Such as General Hindi, General English, General Science Home science etc. Apart from this, there has been a shortage of scientific courses in madrasas. If modern education is included in the madrasas, it becomes difficult to bring teachers to teach them.

Jeffery (2004) studied the Islamic course of girls and found that there are some sections of their Islamic course whose readings are only which they themselves do not know what they read. Modern education has been included less due to poor standard of education of madrasas, as well as due to lack of funds, madrassas have shortage of highly qualified teachers who can teach secular education. Apart from this, in madrasas, girls are offered Fazila degree, Alima degree in which they are also taught to weave, stitch, embroidery, etc. Madrasa

The way in which girls are being taught in madrasas, they are playing their important role in empowering Muslim girls to some extent.

\section{CONCLUSION}

This study highlights the empowerment of women in madrasa education and learning of girls living in madrasas. In today's era, Madrasas are moving towards modernization, girls' madrasas are still lagging behind boys. The madrasa mostly focuses on courses such as sewing, embroidery etc. Apart from this, emphasis was placed on modern education for him, emphasis should be given so that in future they can stabilize himself in a high profile job.

\section{REFERENCES}

1. Nayak, P., \& Mahanta, B. (2012). Women Empowerment in India. Bulletin of Political Economy, 5(2), 155-183

2. Walle, D. (2008). Durkheim and Socialization. Durkheimian Studies, 14, 35-58. 


\section{International Advanced Research Journal in Science, Engineering and Technology}

Vol. 8, Issue 8, August 2021

\section{DOI: 10.17148/IARJSET.2021.8810}

3. Mehra, R. (1997). Women,Empowernment, and Economic Development. Annals of the American Academy of Political and Social Science, 554(1), 136-149.

4. Hazarika, D. (2011), Women Empowerment in India: A Brief Discussion. International Journal of Educational Planning \& Administration, 1(3), 199-202.

5. Singh, P., \& Bhandari, M. (2017). Literacy Level of Muslim Girls in Uttar Pradesh. International Journal of Advance Research, Ideas and Innovations in Technology , 3 (3), 1079-1084.

6. Biswas, R. (2016). Higher Education for Muslim Women Empowerment in India. International Journal Of Scientific Research And Education , 4 (8), 5661-5664.

7. Ali, A. (2001). Muslims and Education. Economic \& Political Weekly, 36(34), 3221-3222.

8. Sikand, Y. HomeThe Role of Girls' Madrasas in India. Islamic Research Foundation International, Inc.https://www.irfi.org/articles/articles_401_450/role_of_girls.htm, Last accessed on 10/12/2020.

9. Borker, H. (2018). Madrasas and the Making of Islamic Womanhood. Contributions to Indian Sociology 53(3), 463-465.

10. Nikhat Tabasum; B S Hugar. "Gender Differences Pertaining To Work-Life Balance". International Research Journal on Advanced Science Hub, 2, Special Issue ICARD 2020, 2020, 187-192. doi: 10.47392/irjash.2020.117

11. Jeffery, P., Jeffery, R., \& Jeffery, C. (2004). Islamization, Gentrification and Domestication: 'A Girls' Islamic Course' and Rural Muslims in Western Uttar Pradesh. Modern Asian Studies , 38(1), 1-53 